\title{
EDMUND HUSSERL I FILOZOFIA RADYKALNEGO POCZĄTKU
}

Jacek Migasiński

Marek Pokropski

Uniwersytet Warszawski

Nie ulega wątpliwości, że Edmund Husserl, twórca filozofii fenomenologicznej, zajmuje zasłużone miejsce wśród klasyków XX-wiecznej filozofii. Jako ów twórca jest postacią pomnikową, ale na skutek szerokiej recepcji bywa też kojarzony z licznym gronem filozofów reprezentujących różne opcje światopoglądowe, religijne i polityczne, inspirujących się mniej lub bardziej jego pracami (m.in. M. Heidegger, J.-P. Sartre, M. Merleau-Ponty, J. Derrida, E. Levinas, H.-G. Gadamer, P. Ricœur). Według niektórych innych kojarzy się z wyjątkowo nudnym i suchym, najeżonym neologizmami, sposobem prowadzenia wywodu filozoficznego, oderwanego od „naturalnej” postawy wobec świata. Natomiast dla badaczy historii myśli fenomenologicznej jest, poprzez swoją ponadtrzydziestotomową spuściznę wydawaną w większości na podstawie roboczych manuskryptów, myślicielem czasami niespójnym i stanowiącym poważny problem interpretacyjny. W pracach poświęconych myśli Husserla (np. Spiegelberg 1972; Święcicka 1993; Zahavi 2012) dominuje zazwyczaj opisywanie go za pomoca figury ojca założyciela, pierwszego fenomenologa proponującego nowa pozytywną metodę analiz filozoficznych albo autora bardzo szczegółowych rozważań epistemologicznych, korygujących dotychczas popełniane nieścisłości. Takie interpretacje zdają się przesłaniać rzecz bardzo istotną w filozoficznym projekcie Husserla, mianowicie jego radykalizm. W niniejszym tekście postaramy się pokazać, na czym ów radykalizm polegał. Zaczniemy 
od krótkiej rekonstrukcji motywów, jakie skłoniły Husserla do porzucenia obiecującej kariery matematyka i wejścia na ścieżkę pracy filozoficznej. Stawiamy tezę, że dominującym motywem zmiany w życiu Husserla była duchowa przemiana o charakterze religijnym i metafizycznym. Następnie przedstawimy Husserla krytykę dotychczasowego sposobu uprawiania filozofii. Zdaniem Husserla filozofia, a mówiąc ogólniej sama racjonalność naukowa, przechodzi głęboki kryzys. Dlatego Husserl projektuje nową naukę, która ma prowadzić do odnowy racjonalności, a w efekcie do odnowy duchowej kondycji człowieka. Na koniec zastanowimy się, z jakimi ograniczeniami i kłopotami Husserl w swoim maksymalistycznym projekcie musiał się zmagać.

\section{/// Filozoficzna przemiana}

Na szczególną uwagę zasługuje droga Husserla do filozofii - wszak filozofem z wykształcenia on nie był. Karierę akademicką zaczynał jako bardzo uzdolniony i obiecujący matematyk, współpracując już w młodym wieku, w latach 1877-1881, z tak wybitnym matematykiem, jak Karl Weierstrass. Husserl przyjaźnił się również z twórcą teorii zbiorów Georgiem Cantorem i przez wiele lat pozostawał w kontakcie ze środowiskiem matematyków skupionych wokół Davida Hilberta na Uniwersytecie w Getyndze. Pierwsza ważna praca Husserla zatytułowana Philosophie der Arithmetik (1891) dotyczyła właśnie filozofii matematyki, a w szczególności budowania systemów numerycznych i funkcji rozumianych jako procedury numerycznych konstrukcji.

W jaki sposób Husserl stał się filozofem? Co skłoniło matematyka do podjęcia trudu badań filozoficznych i zbudowania nowej filozofii nazwanej fenomenologia? Według dominującej opinii zasługę tę przypisuje się nauczycielowi Husserla Franzowi Brentano, który zaproponował metodę psychologii opisowej oraz powiazzał temat świadomości z intencjonalnością, co stało się potem jednym z głównych tematów badań fenomenologicznych. Inny trop możemy odnaleźć w korespondencji Husserla z Gottlobem Frege (zob. Mohanty 1974), w której dyskutuja nad możliwościa opisu logicznej struktury języka naturalnego. Sam Husserl będzie ten temat podejmował w wielu swoich pracach (np. Badania logicæne oraz Logika formalna i logika transcendentalna). Mogłoby się więc wydawać, że to właśnie zainteresowania naukowe, a dokładnie logika stała się naturalnym pomostem, po którym Husserl matematyk przeszedł do obszaru badań filozofii transcendentalnej. 
Istnieje jednak jeszcze jedna odpowiedź na postawione powyżej pytanie. Jak czytamy w liście Husserla z 1919 roku do swojego ucznia i przyjaciela Arnolda Metzgera, powód porzucenia dotychczasowych zainteresowań był inny. Tym, co spowodowało zwrot Husserla ku filozofii, było głębokie przeżycie duchowe i religijne oraz przekonanie o kryzysie, w jakim znalazła się kultura europejska. Jak Husserl wyznaje w liście: „decydujące bodźce (które pchnęły mnie od matematyki do zawodowego uprawiania filozofii) leżały w sferze przemożnych przeżyć religijnych i [związanej z nimi mojej] zupełnej przemiany. To bowiem potężny wpływ Nowego Testamentu na dwudziestotrzylatka wyraził się przecież w dążeniu, żeby przez ściśle filozoficzną naukę odnaleźć drogę do Boga i do życia w prawdzie" (Husserl 2009: 538). Pod wpływem tego przeżycia pochodzący z żydowskiej rodziny Husserl w 1886 roku przyjmuje chrzest w kościele ewangelickim. Religijne motywy intelektualnej przemiany sa zaskakujace o tyle, że w swoich publikowanych pracach Husserl w zasadzie nie podejmuje zagadnienia Boga, podążając w ten sposób konsekwentnie za przyjętą zasadą redukcyjna, według której źródłem prawomocności poznania jest „źródłowo prezentująca naoczność", czyli to, co się jako analogon zmysłowego spostrzegania w świadomości przedstawia. Jak pisze w Ideach I: „Na ten «absolut» i «transcendents» rozciągamy naturalnie fenomenologiczną redukcję. Winien on zostać wykluczony z tego pola badania, które mamy od nowa stworzyć, o tyle, o ile ma ono być polem samej czystej świadomości” (Husserl 1967: 189). Kiedy już jednak Husserl stara się coś o Bogu powiedzieć, to zgodnie z ową redukcyjna zasadą dochodzi do fantastycznego wniosku, że Bóg jako „duch absolutny” dla celów wzajemnego porozumiewania się z nami, ludźmi, „musiałby posiadać ciało, a więc i tu zachodziłaby zależność od narządów zmysłowych” (Husserl 1974: 120-121).

Jednakże tego rodzaju powściągliwość zachowuje Husserl w pracach opublikowanych za życia. W manuskryptach publikowanych wiele lat później w serii Husserliana konieczność przyjęcia istnienia Boga zostaje wyeksponowana jako niezbędne dopełnienie i zwieńczenie analiz transcendentalno-ejdetycznych. Już na poziomie przeżyć indywidualnego Ja transcendentalnego ujawnia się, dzięki intencjonalności świadomości, teleologiczny charakter konstytuowanego przez nie świata. Również z uniwersalnej perspektywy w dziejach rozwoju świata można, zdaniem Husserla, rozpoznać teleologię. Jednak ponieważ istnienie monadycznego Ja, a nawet intersubiektywnej wielości monad jest faktyczna przypadkowością, więc istnienie świata w jednozgodnym przebiegu minionych, aktualnych i przyszłych doświadczeń można racjonalnie wytłumaczyć, jedynie przyjmując 
istnienie „wszechświadomości” różnej od zbioru świadomości monadycznych, pewnego „wszech-Ja”, które jest „absolutnym Logosem”, podstawa teleologicznych związków utożsamianą z Bogiem. Tym samym w centrum postulowanej przez Husserla „teleologicznej metafizyki”, tłumaczącej irracjonalność faktyczności wymykającej się prawom ejdetycznym i poruszającej „najwyższe i ostateczne problemy”, stoi idea Boga, a metafizyka ta jest „nierozerwalnie związana nie tylko z teleologia, lecz także z teologia”" (Lee Chun Lo 2009: 337-351 oraz Laciak 2015: 256-277).

Zapewne nie bez znaczenia dla tej dwoistej strategii myślowej jest fakt, że Husserl podkreśla w liście do Metzgera swoja „ściśle filozoficzną”, a mówiąc inaczej, czysto teoretyczna postawę, którą przeciwstawia praktycznej działalności. Jak stwierdza w tym samym liście: „Nie jestem powołany na wodza poszukującej «zbawienia» ludzkości - w nawale cierpień lat wojennych musiałem to uznać, mój dajmonion mnie ostrzegł. W pełni świadomie jestem zdecydowany żyć jako czysto naukowy filozof" (Husserl 2009: 539). W ten sposób Husserl dystansuje się od roli zaangażowanego intelektualisty, którego modelowym przykładem był właśnie adresat listu, czyli Metzger - ochotnik na front w I wojnie światowej i autor Pbänomenologie der Revolution (1979) wpisującej się w nurt utopijnego socjalizmu. Jakkolwiek Husserl docenia etyczny radykalizm i maksymalizm filozofii Metzgera wszak zdaniem Husserla prawdziwa filozofia musi być zawsze radykalna - oraz krytykę kapitalizmu, w którym twórca fenomenologii dostrzegał wyraz bezideowego egoizmu, to jednak dystansuje się od żywiołowej i zaangażowanej postawy swojego ucznia i zwraca uwagę na ,niedostatecznie naukowy” charakter jego rozprawy (Gniazdowski 2007: 93). Z jednej strony wydaje się, że próby pohamowania młodzieńczego entuzjazmu Metzgera moga wynikać z bolesnych osobistych przeżyć Husserla, którego jeden z synów zginął na wojnie w 1916 roku, a drugi został poważnie ranny (obaj tak samo jak Metzger byli ochotnikami). Z drugiej strony, w postawie Husserla kryje się etos czystego teoretyka krytycznie zapatrującego się na nieprzemyślane i naiwne działania podejmowane bez wystarczającego rozważenia wszystkich racji i odniesienia do teleologicznej idei Boga. W liście stwierdza:

Mówiąc otwarcie, moje ogólne wrażenie z Pańskich rozważań z historii idei jest takie, że nie wykształcił Pan w sobie jeszcze w pełni zmysłu dla ducha historii, tak samo jak ja dopiero bardzo późno dostrzegłem, jak się on we mnie kształtuje. (Przypuszczam w związku z tym, że również Pan wyszedł od studiów przyrodni- 
czych). Bóg i świat Boży, szukający Boga, jako dziecko Boże żyjący człowiek itd. - wszystko to zacznie znaczyć dla Pana coś nowego, bogatszego, kiedy tylko zyska Pan oko do historii i - co wcale od tego nieodległe - oko do absolutnej samoobserwacji, a także obserwacji ,świata” jako bieguna czystej subiektywności (Husserl 2009: 540).

Jednak jak zauważa Gniazdowski (2007: 98-99), list do Metzgera nie jest jednoznaczną krytyką młodszego i zaangażowanego intelektualisty, ale jest próbą połączenia obu etosów: teoretycznego i praktycznego. Świadczy o tym uwaga, że relacja między ,nowym ruchem rewolucyjnym a fenomenologia” jest dla Husserla „frapująca”, choć jeszcze niedostatecznie przez niego uchwycona (Husserl 2009: 542). Jak Husserl przyznaje w liście, intelekt jest w pewnym sensie sługą woli, a teoretyk podlega w jakimś stopniu „przewodnikom ludzkości”. Ważniejsze jest jednak, że zarówno praktyczna filozofia rewolucji Metzgera, jak i czysto teoretyczna fenomenologia Husserla są odpowiedzią na zgodną diagnozę w nich zawarta. Obie, jak stwierdza Husserl, zrodziły się „z potrzeby, z niewypowiedzianej potrzeby duszy, z zupełnego «załamania», z którego był tylko jeden ratunek: zupełnie nowe życie, rozpaczliwie i zacięcie zdecydowane, aby radykalnie uczciwie zaczać je od nowa i kontynuować, nie cofając się przed żadnymi konsekwencjami” (Husserl 2009: 538). W obliczu głębokiego kryzysu, jaki, zdaniem obu filozofów, dotknął kulturę europejska, obie postawy sa uzasadnione i obie chcą zastaną sytuację przezwyciężyć. Husserl wybiera drogę teoretyczną i czysto naukowa, gdyż to w samej nauce i stosowanych modelach racjonalności upatruje zarazem źródeł kryzysu, jak i nadziei na odnowę duchową ludzkości. Ale to ta nadzieja jest głównym motorem napędowym jego pracy.

\section{/// Krytyka filozofii i kryzys nauk}

Husserl swoją ocenę filozofii wyłożył m.in. w pracy z 1911 roku pt. Filozofia jako ścisła nauka (1992). Nie będąc filozofem z wykształcenia, Husserl jest niesłychanie krytyczny względem filozofii, zarzucając jej przede wszystkim nienaukowość. Filozofia, jego zdaniem, nie potrafiła nigdy spełnić swojej pretensji do bycia nauką w rozumieniu ścisłej (strenge) naukowości. Zauważmy przy okazji, że niemiecki termin strenge oznacza tutaj naukowy rygoryzm, który ma przyświecać fenomenologii, a nie formalną ścisłość 
w znaczeniu nauk matematyczno-fizycznych, która określana jest niemieckim terminem exakte.

Husserl w swojej ocenie jest bardzo radykalny - pisze: „nie mówię, że filozofia jest nauką niedoskonałą; mówię wręcz, że w ogóle nie jest ona jeszcze nauką, że nie rozpoczęła się jako nauka" (Husserl 1992: 8-9). Opinia Husserla nie jest jakże częstym w dzisiejszych czasach narzekaniem „ścisłowca” na „nienaukową" i bezproduktywną humanistykę. Husserl doskonale rozumie istotę humanistyki i widzi doniosłość filozofii, przyznaje jej wręcz miejsce „najwyższej i najściślejszej z nauk”, która jednak nie potrafiła nigdy swojej obietnicy poznania absolutnego spełnić. Jak ujmuje to zwięźle w liście do Metzgera:

[...] filozofia współczesna, która tak obnosi się ze swoją naukowością, zupełnie zawiodła i w ten sposób uwłacza idei filozofii - aby być najbardziej radykalnie rzetelnym spełnieniem wszelkiej nauki. Zawiodła nie tylko ona, lecz również wszelka filozofia będąca dziedzictwem historii - wszędzie niejasność, niedojrzałe dywagacje, połowiczność lub w ogóle intelektualna nierzetelność (Husserl 2009: 538).

Co gorsza, marna kondycja filozofii jest symptomem dużo poważniejszej choroby, mianowicie kryzysu naukowej racjonalności.

Wszystkie nauki, według Husserla, sa niedoskonałe (sa niezupełne, mają braki teoretyczne i niekończące się pole problemów), ale jest to naturalna konsekwencja rozwoju nauki. Budowanie korpusu wiedzy naukowej jest bowiem zadaniem nieskończonym, rozciagającym się na pokolenia ludzkości. Nauki przyrodnicze i ścisłe sa jednak w bez porównania lepszej sytuacji niż filozofia, w której „wszystko bez wyjątku jest sporne” (Husserl 1992: 10) i która nie dysponuje żadnym systemem teoretycznym. Przewrót kartezjański, który położył podwaliny pod współczesną naukę i metodę naukowa, sprowadzająca się w dużej mierze do wykorzystania matematyki do opisu i modelowania świata, przyczynił się do niebywałego rozwoju nauk przyrodniczych i ścisłych. Husserl to dostrzega i docenia wielkość czasów, w których żyje. Pozostaje jednak krytyczny, gdyż sformułowana w podobnym duchu obietnica uniwersalnej i ścisłej filozofii nie została, według niego, spełniona. Tak radykalnie negatywna ocena filozofii ze strony Husserla może budzić wątpliwości; wszak istnienie rozbudowanych systemów filozoficznych było w owym czasie faktem, wystarczy wymienić systemy filozoficzne niemieckich idealistów, począwszy od fundamentalnego 
systemu filozofii transcendentalnej Kanta. Husserl oczywiście prace Kanta znał i przejął częściowo jego transcendentalny punkt widzenia, jednak dla niego ta „rewolucja kopernikańska” była niewystarczająca. Kantowski system krytyki rozumu również nie jest ścisłą i naukową filozofią, gdyż brakuje mu „rzetelnego fenomenologicznego pojęcia apriori”, pozwalającego w bezpośrednich ,wglądach” przebadać „czyste prawa płynące z istoty, którym podlegaja akty jako przeżycia intencjonalne" (Husserl 2000b; 243-244). Prawdziwie naukowa filozofia ma dopiero nadejść wraz z pojawieniem się fenomenologii i jej metody.

Nowożytny model nauki, stawiający matematyczną ścisłość jako wzór naukowości, przyniósł, oprócz rozwoju przyrodoznawstwa, wyłonienie się dwóch dominujących światopoglądów: naturalizmu oraz jego antytezy w postaci historyzmu. Obie te tendencje, występujące zarówno w nauce, jak i w filozofii, Husserl krytykuje. Jego zdaniem sa one fałszywymi odpowiedziami na próbę ustanowienia filozofii ściśle naukowej, a zarazem są wyrazem zagubienia naukowej racjonalności. Kryzys nauki nie polega bowiem na braku postępu, ale na tym, że „problematyczna stała się jej autentyczna istota, cały jej sposób stawiania sobie zadań i wypracowywania odpowiedniej do nich metody” (Husserl 2017: 17). Doszło do „pozytywistycznego zawężenia idei nauki", które wykluczyło pytania o sens i istotę racjonalności, a człowieka i jego świat sprowadziło do zbioru faktów, czy to przyrodniczych, czy historycznych.

Naturalizm ujmuje przyrodę jako czasoprzestrzenny byt podlegający ścisłym prawom przyrodniczym (Husserl 1992: 14). Zwolennik naturalizmu, zdaniem Husserla, wszystko rozpatruje jako część tak rozumianej przyrody. Takie podejście doprowadziło do rozwoju nauk przyrodniczych i w zasadzie nie byłoby w tej postawie nic problematycznego, gdyby w obręb przyrody naturalista nie włączał również domeny aksjologicznej, praw logicznych oraz świadomości i intencjonalności (własności stanów umysłowych stanowiącej o ich odniesieniu do jakiegoś przedmiotu - mówiąc krótko, stany mentalne są „o czymś”). Husserl zdecydowanie przeciwstawia się tym tendencjom. W pierwszym tomie Badań logicznych zwalcza psychologizm sprowadzający logiczne prawa myślenia do praw psychologicznych. W późniejszych pracach odnosi się krytycznie do prób naturalistycznego wyjaśnienia świadomości i intencjonalności. Taka redukcyjna, używając dzisiejszej terminologii, naturalizacja świadomości jest dla fenomenologa pomyłką wynikającą z niezrozumienia zarówno samej natury świadomości, jak i podstaw nastawienia naturalistycznego. Naturalista nie dostrzega bowiem, że jego nastawienie poznawcze zasadza się na milczącej przesłan- 
ce istnienia świadomości w obrębie świata. Mówiąc inaczej, świadomość nie może zostać znaturalizowana, gdyż nie jest zwykłą częścią świata naturalnego - tak, jak kamienie, zwierzęta i chmury - ale jest samym sposobem (aktywnościa), w jaki sens przedmiotowy, w tym i sens świata naturalnego, powstaje.

Husserl nazywa wprost projekt naturalizacji świadomości przesądem. Jak pisze w Idei fenomenologii: „Przypominam o jakże chętnie przeprowadzanych uzasadnieniach teorii poznania poprzez psychologię poznania i biologię. Ostatnio podnosi się reakcja przeciw tym fatalnym przesądom. W rzeczy samej, to sa przesądy” (Husserl 1990: 34). Już w Badaniach logic₹nych Husserl ustalił hierarchę fundowania pomiędzy ,apriorycznym poznaniem kategorialnym" a wszelkimi teoriami empirycznymi: otóż to pierwsze poznanie, jako „teoria teorii”, sytuuje się „przed nauką o fizycznej przyrodzie”, „przed psychologia” i „naturalnie także przed wszelką metafizyka”, bo polega na „rozjaśnieniu” idei poznania „co do jej konstytutywnych elementów”, które przebiega w ramach fenomenologii ,ukierunkowanej ku istotowym strukturom «czystych» przeżyć” i ich „zasobów sensu” (Husserl 2000a: 29-30).

Wynikające z niezrozumienia tej hierarchii przesądy obecne są także w samej psychologii, która dla Husserla ma szczególne znaczenie. Jego zdaniem psychologia eksperymentalna, tak samo jak biologia, to nauka o faktach i jako taka nie jest w stanie wyjaśnić ani zasad myślenia (logika), ani wiedzy praktycznej (aksjologia, etyka), ani tym bardziej istoty świadomości. Dziedzin tych nie da się w tym sensie znaturalizować, czyli zredukować do faktów przyrodniczych. Nie oznacza to bynajmniej, że Husserl jest przeciwnikiem tak rozumianej psychologii. Zwraca on tylko uwagę na to, że psychologia eksperymentalna pozwala jedynie ustalić „wartościowe psychofizyczne fakty i prawidłowości, które wszakże bez systematycznej nauki o świadomości, immanentnie badającej byt psychiczny, pozbawione są możliwości głębszego zrozumienia" (Husserl 1992: 27). Roszczenie psychologii eksperymentalnej do bycia nauką o świadomości nie może zostać spełnione, jest wręcz, zdaniem Husserla, niedorzeczne, gdyż opiera się ona na „ułudzie przyrodniczej metody” (tamże: 35), na błędnym założeniu, że metoda przyrodoznawstwa może zostać zaaplikowana do badania świadomości. Nauka o tym, co psychiczne, jest możliwa, ale wymaga radykalnej zmiany nastawienia z naturalistycznego na fenomenologiczne, czyli ujmując rzecz skrótowo, na takie, w którym możliwy będzie czysty ogląd ,istoty" świadomości. Tylko taka psychologia fenomenologiczna może zreformować psychologię empiryczną. 
$[\mathrm{N}]$ aprawdę zadowalająca empiryczna nauka o tym, co psychiczne, [ujmowanym] w jego związkach z przyrodą będzie mogła rozwinąc się dopiero wtedy, kiedy psychologia oprze się na systematycznej fenomenologii; kiedy zatem wyznaczane przez istotę postacie świadomości i jej immanentnych odpowiedników, czysto oglądowo zbadane i określane w systematycznym porządku, podyktuja normy regulujące naukowy sens i treść pojęć wszelkiego rodzaju fenomenów, czyli pojęć, za pomocą których empiryczny psycholog wyraża w swoich psychofizycznych sądach sama psychikę (tamże: 51).

Prawdziwie naukowe badanie świadomości powinno, zdaniem Husserla, opierać się na czystym oglądzie struktury świadomości. Jest to rozwinięcie psychologii opisowej Brentana, a zarazem jednoznaczne opowiedzenie się za możliwością naukowej analizy doświadczenia. Projekt Husserla jest również rodzajem filozofii transcendentalnej, szukającej jednak warunków możliwości doświadczenia w czystym oglądzie, a nie w dedukcji, jak u Kanta. Należy przy tym zaznaczyć, że podejście Husserla to nie introspekcjonizm, który twórca fenomenologii uważał za naiwny i bezkrytyczny sposób opisu wewnętrznego doświadczenia. Husserlowi chodzi natomiast o to, że możemy w sposób ścisły i metodyczny analizować nasze doświadczenie w celu wydobycia jego uniwersalnej struktury, abstrahując od indywidualnych uwarunkowań. (Szerzej o metodzie fenomenologicznej w kolejnym punkcie.)

Podsumowując, naturalizm jest, według Husserla, postawą naiwną i to w sposób nieuleczalny, tzn. „naiwność”, czyli taktowanie przyrody po prostu jako „danej”, jest niejako wpisana zarówno w samą konstrukcję takiego światopoglądu, jak i przyrodniczych metod badawczych (Husserl 1992: 21). Naturalizm, który z jednej strony jest niesłychanie wymagający (weryfikacja teorii poprzez konfrontację $z$ empiria), z drugiej strony jawi się jako postawa bezkrytyczna względem swoich podstaw. Jest to światopogląd niepotrafiący rozpoznać swoich fundamentów, a przez to uwikłany we własne założenia, co prowadzi do nonsensownych, zdaniem Husserla, prób znaturalizowania zjawisk i obszarów rzeczywistości, których włączyć w obręb przyrody się nie da.

Druga z dominujących tendencji światopoglądowych to historyzm, który Husserl określa mianem „teoriopoznawczej aberracji” również prowadzącej do licznych niedorzeczności (1992: 61). O ile historyzm słusznie uznaje, że pewne fakty i znaczenie, jakie im przypisujemy, są wynikiem 
procesów historycznych, budujących „społecznego ducha” (Gemeingeistes) wspólnoty, a więc fundament powszechnej obyczajowej obowiązywalności, to jednak prowadzi wprost do „filozofii światopoglądowej”, będącej wyrazem panującego popularnego ducha danej epoki. Jest to o tyle niebezpieczne, że prowadzi do sceptycyzmu i relatywizmu, a ostatecznie do ujmowania wszelkich prawd i norm jako kwestii czasowo uwarunkowanych światopoglądów. Husserl wierzy jednak, że ponad tym, co historyczne i zmienne, ponad sfera faktów historycznych i kulturowych, istnieją niezmienne struktury czy też „istoty”, np. świadomość, wartości czy prawa logiczne. I to te obszary są wyzwaniem dla przyszłej nauko wej filozofii.

Oddzielenie idei światopoglądu od idei nauki jest w dużej mierze odpowiedzialne za duchowy kryzys ludzkości. O ile w starożytności, zdaniem Husserla, obie idee pokrywały się ze sobą w dążeniu do mądrości, o tyle od czasów nowożytnych nastapiło ich rozdzielenie. Światopogląd stał się czymś zależnym od epoki historycznej lub doraźnej mody, a mówiąc inaczej, stał się czymś zmiennym i przemijającym. Tymczasem idea nauki jest ponadczasowa, wykracza poza historyczne momenty i aspiruje do obiektywności. Ten podział skutkuje, z jednej strony, podważaniem i niezrozumieniem idei nauki, z drugiej zaś, oderwaniem się nauki od świata życia (Lebenswelt), popadnięciem racjonalności naukowej w bezkrytycyzm, co sprawia, że sama istota nauki staje się „problematyczna”.

Wszystkie opisane powyżej postawy i tendencje występujące w czasach Husserla w Europie prowadzą do kryzysu etycznego, kryzysu duchowości, który wynika z pogubienia się co do istoty racjonalności. Z jednej strony, zagadnienia świadomości i rozumu rugowane są ze świata nauki, w którym dominować zaczęła wąsko rozumiana racjonalność praktyczna i naturalistyczna. Z drugiej strony, filozofia sama jest w opłakanej kondycji i zamiast wejść na ścieżkę nauki, wikła się w spekulacjach i relatywizmie. Dla Husserla filozofia ma ogromną misję do spełnienia, musi podjąć trud zrozumienia, czym jest świadomość, czym jest rozum przejawiający się w różnorodnych formach. Husserl przyznaje, że są to zagadnienia o dużym ciężarze metafizycznym, grożące spekulacja, ale jak stwierdza: „niech dla filozoficznych pacholąt będzie to ciemny zaułek, w którym straszą upiory solipsyzmu, psychologizmu czy relatywizmu. Prawdziwy filozof nie ucieka [ze strachu] przed nimi i [stara się] prześwietlić ten ciemny zaułek" (Husserl 2011: 231). Filozofia ma więc odważnie podjać postawione przed nia zadanie, a co więcej, twórca fenomenologii przypisuje jej rolę przewodnią w mającej powstać ponadnarodowej wspólnocie naukowców, wszech- 
wspólnocie kierującej się ideałem nieskończonej i wielowymiarowej racjonalności (Husserl 1993: 36-37).

Według Husserla, słabość filozofii i zbłąkana, zredukowana do jednego wymiaru racjonalność nie jest przypadłością marginalną, naskórkową, czymś, co dotyczy jedynie naukowców, ale przenika duchowe życie Europejczyków. Pisze on: „Duchowa nędza naszych czasów stała się faktycznie nie do zniesienia. [...] Tym jednak, co cierpimy, jest raczej najbardziej radykalna nędza ஷ̇yciowa, nędza, która nie ustaje w żadnym momencie naszego życia” (1992: 72). W innym miejscu w jeszcze bardziej alarmistycznym tonie dodaje: „Istnieją tylko dwa wyjścia z kryzysu europejskiego sposobu istnienia: upadek Europy przez wyobcowanie ze swego własnego racjonalnego sensu życiowego, popadnięcie we wrogość wobec ducha i barbarzyństwo, albo też odrodzenie Europy z ducha filozofii przez heroizm rozumu przezwyciężającego ostatecznie naturalizm” (1993: 51).

Warto w tym miejscu rozjaśnić, czym dla Husserla jest Europa i skąd w jego filozofii ten europocentryzm. Jak zauważa Miettinen (2013), zagadnienie Europy w pracach Husserla zdecydowanie wykracza poza jego pisma krytyczne względem europejskiej nauki i sytuacji społeczno-kulturowej. Husserl, jak widzimy, był głęboko poruszony stanem duchowego życia Europejczyków. Silnym wstrząsem skłaniającym Husserla do refleksji na temat kondycji Europy była I wojna światowa oraz czas powojenny w Republice Weimarskiej. Jego przemyślania skłaniają się jednak do ukazania ogólnego sensu Europy jako pewnej idei. Przede wszystkim Europa jest dla twórcy fenomenologii kolebką filozofii rozumianej jako projekt uniwersalności rozumu prowadzący do ukonstytuowania się jedności świata. Filozoficzna analiza dziejów i intelektualnych przemian Europy, którą Husserl najpełniej przedstawia w Kryzysie (2017), ujawnia teleologiczny proces rozwoju racjonalności, która urzeczywistnia się w formach życia społeczno-kulturowego, które w sposób racjonalny uspójniały kolejne obszary rzeczywistości. Taka filozofia dziejów rozumu może na pierwszy rzut oka wydawać się podobna do Heglowskiego pochodu rozumu. Jak jednak zauważa Święcicka (1993: 108-110), choć u Husserla również mamy dziejowy proces powstawania samowiedzy, to nie ma w nim takiej pewności i determinizmu, jak u Hegla. Rozum może zbłądzić, a nawet ponieść klęskę, dlatego u Husserla tak alarmistyczny ton i przekonanie, że od jego projektu może zależeć przyszłość Europy. Przeciwnie niż u Hegla rozwój rozumu jest, według Husserla, nieskończony, a sama idea racjonalności ma charakter normatywny, a nie spełniający się adekwatnie w rzeczywistości. Mówiąc inaczej, nawet jak racjonalność jest na właściwej drodze, proces 
samowiedzy nie może się domknąć, ale wyznacza kolejnym pokoleniom sposób postępowania.

Najpełniejszym wyrazem dziejowego procesu racjonalności jest dla Husserla nauka, a w szczególności nauki posługujące się metodami matematycznymi, oraz wspólnota badaczy ucieleśniająca naukowe praktyki. Wspólnota badaczy nie może ograniczać się do teraźniejszości, ale niesie ze sobą osiagnnięcia przeszłych pokoleń oraz projektuje kontynuację procesu tworzenia wiedzy w pokoleniach przyszłych. Dlatego Husserl ściśle łączy ideę Europy i ideę racjonalności z idea generatywności, tzn. swego rodzaju sedymentacji sensu i kontynuowania procesu tworzenia wiedzy przez przyszłe pokolenia. Jednak kryzys, który, jak już wiemy, polega na zbłądzeniu racjonalności naukowej, nie dotyczy wyłącznie naukowców, lecz dotyka wszystkich obszarów naszego życia. Dzieje się tak właśnie dlatego, że jego źródło tkwi w samym racjonalnym jądrze europejskości. Kryzys jest więc choroba, która toczy życie Europy i która, jeśli nie zostanie powstrzymana, doprowadzi do jej upadku. Wyjściem z kryzysu nie może być jednak działanie praktyczne rozumiane jako społeczna i polityczna rewolucja, jak chciał tego Metzger. Wydaje się, że dla Husserla takie rozwiązania są doraźnymi lekami na objawy kryzysu, a nie terapią skierowaną na jego przyczynę. Dlatego rozwiązanie Husserla jest diametralnie inne - uratować Europę może tylko rewolucja myślenia oraz odnowienie nauk w duchu nieskończonej, traktowanej normatywnie idei rozumności. Jak pisze: „Nędza pochodzi tutaj z nauki. Ale tylko nauka może ostatecznie przezwyciężyć nędzę, która pochodzi z nauki" (Husserl 1992: 73-74). Husserl wybiera więc życie czystego teoretyka, wierząc, że odpowiednio radykalny projekt filozoficzny możne odmienić świat.

\section{/// Filozofia radykalnego początku}

Pogrążoną w kryzysie duchowym Europę może, zdaniem Husserla, uratować jedynie prawdziwie naukowa filozofia, która oprze racjonalność na nowych podstawach. Fundamentów nie da się bowiem zbudować na istniejących już konstrukcjach. Dlatego, jakkolwiek szalonym może się wydawać taki zamiar, Husserl proponuje odrzucić wszelkie filozoficzne osiagnięcia i rozpocząć filozofię od nowa. Wskazówką, jak zbudować nową ściśle naukową filozofię, jest postępowanie Kartezjusza, który przez metodyczny sceptycyzm doszedł do odkrycia sfery czystego myślenia. Jednak, zdaniem Husserla, Kartezjusz zaprzepaścił swoje odkrycie, ontologizując ego cogito, czyli powiadając: ,jestem ržeczq myślącą”. Stał się przez to ojcem pewne- 
go - pisze Husserl - „niedorzecznego transcendentalnego realizmu”, zachowującego „małą cząstkę świata” w czystym ego (Husserl 1982: 34-35). Tym samym Kartezjusz zamknął drogę do badania świadomości transcendentalnej jako fundamentu poznania. Jak stwierdza Husserl w Medytacjach kartezjańskich: „Na tę drogę chcemy teraz wstapić, jako filozofowie radykalnego punktu wyjścia zamierzamy w quasi-kartezjański sposób spełniać akty medytacji” (Husserl 1982: 8). Ów quasi-kartezjański sposób „medytowania" ma, podobnie jak u Kartezjusza, zasadzać się na metodycznym sceptycyzmie i odrzucaniu wszystkiego, co wątpliwe, ale ma też unikać jego błędów. Jak ma więc wyglądać pierwszy krok nowej filozofii? Oto on: „Gdy jednak wykładając sens naszej epoki zwracamy się ku temu wielkiemu celowi, to musimy też jasno sobie uświadomić, że możemy go osiągnąć tylko w jeden sposób: mianowicie jeżeli z radykalizmem, który należy do istoty rzetelnej nauki filozoficznej, nie przyjmujemy niczego zastanego, nie uznajemy za początek niczego przejętego z tradycji i nie dajemy się zaślepić przez żadne, choćby największe nazwisko, lecz usiłujemy dopracować się początków, z własnej woli poddani samym zagadnieniom i posłuszni wynikającym z nich wymaganiom" (Husserl 1992: 78).

Środkiem, który ma zapewnić spełnienie tak radykalnych oczekiwań nowej filozofii, ma być redukcyjna metoda fenomenologiczna. Ramy tego skromnego opracowania nie pozwalają przedstawić całej złożoności metody fenomenologicznej wraz z jej interpretacjami (zob. omówienie metody fenomenologicznej np.: Święcicka 1993; Krokos 1998; Płotka 2019). Przedstawimy tylko zarys tej metody, warto jednak również zaznaczyć, że u Husserla nie przyjęła ona nigdy ostatecznej formy. W Ideach I wyłania się obraz pewnego ideału metody, do którego praktykujący fenomenolog może dążyć, ale nigdy go nie osiągnie. Jak pisał Merleau-Ponty: „Największą nauka, jaka płynie z redukcji, jest niemożliwość redukcji zupełnej. Oto dlaczego Husserl zastanawia się wciąż na nowo nad możliwością redukcji”' (2001: 11). Niemożliwość redukcji zupełnej ujawnia nam głęboką prawdę o nas samych - jesteśmy bytem-w-świecie, relacją ze światem, którą przerwać może jedynie śmierć. Ale żeby ów przykryty oczywistością stosunek do świata odsłonić, konieczny jest zabieg redukcji. Zaś redukcja odsłania pole badań fenomenologicznych z naczelnymi tematami, takimi jak intencjonalność, czasowość, cielesność, intersubiektywność. Fenomenolog musi ponawiać zabiegi redukcji i ja modyfikować, aby docierać do każdorazowo innego pola tematycznego. Dlatego też Husserl w swoich pracach publikowanych, jak i w manuskryptach roboczych często cofa się do wstępnego etapu redukcji, prezentuje kolejne poziomy konstytucji świata czy też wpro- 
wadza nowe wersje redukcji (np. w Medytacjach kartęjańskich (1982) redukcję do tego, co własne, która ma pomóc w ujęciu istoty intersubiektywności).

W swojej podstawowej formie fenomenologiczna redukcja ma realizować to, co zdaniem Husserla niezbędne, by odnowić filozofię, mianowicie radykalne zerwanie $z$ tradycją filozoficzną, przyjętymi prawdami, utartymi schematami myślenia czy wreszcie dominującymi nurtami myśli, w tym i ze wspomnianym powyżej naturalizmem i historyzmem. Redukcja ma pozwolić rozpocząć myślenie od nowa. Jej pierwszym krokiem jest zawieszenie wszelkich „przedsądów”, całej wiedzy nabytej w edukacji oraz powszechnych mniemań i przekonań na temat natury świata i psychiki. Następnie redukcja, postępując dalej, bierze za cel to, co ujmowane w aktach postrzegania i myślenia. Przedmioty tych aktów przestają dzięki niej być ujmowane jako obiektywne, istniejacce „tam” przed nami przedmioty świata realnego. Bezrefleksyjnie przyjmowane tezy, ujmujące ich znaczenie w nastawieniu naturalnym, zostają „wzięte w nawias”, wyłączone, co nie znaczy bynajmniej ich unieważnienia, uznania ich fałszywości - ich status pozostaje jedynie zawieszony na czas obowiązywania redukcji. Ale wzięte w nawias pozostaja nie tylko charaktery znaczeniowe ujmowanych przedmiotów, ale także sama „teza generalna” nastawienia naturalnego, czyli przekonanie o realnym istnieniu samego świata i należących do niego obiektów. W opisach doświadczenia po zastosowaniu redukcji Husserl zaleca posługiwać się cudzysłowem, aby odróżnić to, co przed redukcją było postrzeganym np. drzewem, od tego, co po redukcji postrzegane jest jako „drzewo”, czyli fenomen nasycony sensem przedmiotowym. W ten sposób, stosując zabieg redukcji fenomenologicznej, zmieniamy nasze nastawienie z naturalnego, domyślnego i codziennego, by tak się wyrazić, trybu funkcjonowania poznawczego - w którym rzeczy po prostu istnieją w świecie, a ich sens jest bezrefleksyjnie ujmowany - na nastawienie fenomenologiczne, które oczywistość istnienia świata i znaczeń mu przypisywanych problematyzuje i tym samym przygotowuje pole badań fenomenologicznych.

Zdaniem Husserla, dokonanie fenomenologicznej epoché, czyli zawieszenia sądów wiedzy naukowej, a także tzw. „tezy generalnej” naturalnego nastawienia sprawia, że fenomenologia jest nauką bezzałożeniową. Nie wdając się w dyskusje na temat tego, czy fenomenologia naprawdę jest bezzałożeniowa i czy bezzałożeniowość jako zasada metodologiczna jest w ogóle możliwa, można, niejako broniąc Husserla przed krytykami, uznać, że jedynym założeniem fenomenologii jest przedstawiona w Ideach I ,zasada wszelkich zasad”, która głosi, ,że każda źródłowo prezentująca naoczność jest źródłem prawomocności poznania, że wszystko, co się nam 
w «intuicji» źródłowo (by się tak wyrazić: w swojej cielesnej rzeczywistości) przedstawia, należy po prostu przyjąć jako to, jako co się prezentuje, ale także jedynie w tych granicach, w jakich się tu prezentuje" (Husserl 1967: 78-79). Z zasady tej wynika nie tylko zalecenie metodologiczne trzymania się w granicach przejawiania się rzeczy. Pociąga ona za sobą konieczność dalszej radykalizacji redukcji, czyli etap redukcji ejdetycznej, która ma charakter poznania apodyktycznego. Należy przy tym wyraźnie zaznaczyć, że przez istotę rzeczy Husserl rozumie zazwyczaj uzyskane poprzez operację „ideacji” naocznie uchwycone jej pojęcie (Husserl 1967: 20-25, 75-76). Pojęcie ejdetyczne, które zawiera w sobie wszystkiej istotne określenia i prawa rządzące przejawianiem się danej rzeczy - np. tego rodzaju prawem „materialnym" poznania jest niemożliwość przejawiania się koloru bez rozciągłości. Żeby zobrazować, o co mu chodzi, Husserl często posługuje się analogiami matematycznymi; tak więc ujmowane w oglądzie fenomenologicznym istoty zjawisk są analogiczne do istot i praw geometrycznych, które też są odkrywane przez swego rodzaju wgląd w naturę bytów geometrycznych. W liście do Metzgera stwierdza: „mówię o fenomenologii jak matematyk o matematyce: że jest ona nauką autentyczną (echte), czerpaną z czystej oczywistości, polem możliwych zdań prawdziwych i fałszywych - wbrew wszelkim sceptykom i mętnym filozofom [każdy fenomenolog] powie tak, ponieważ widzi” (Husserl 2009: 542). Analogia matematyczna ma oczywiście swoje ograniczenia i Husserl podkreśla, że istoty i prawa matematyczne są innego rodzaju niż istoty i prawa fenomenologiczne. Te pierwsze maja charakter formalny, te drugie - materialny. I tak, jak w matematyce możemy oczekiwać powstania zamkniętych systemów numerycznych, tak przed fenomenologią rozciaga się potencjalnie nieskończona mnogość zjawisk psychicznych. Jak pisze Husserl, „tak oto stajemy przed nauka - o której rozległym zakresie współcześni nie maja jeszcze wyobrażenia - będąca wprawdzie nauką o świadomości, a jednak nie psychologią: przed fenomenologia świadomości" (Husserl 1992: 25). Ta nowa nauka, fenomenologia, ma poprzez wydobywanie ejdetycznych zależności pomiędzy wszelkimi możliwymi przedmiotami ludzkiego doświadczenia ustanawiać sam sens doświadczenia i tym samym dostarczać ostatecznych podstaw dla nauk formalnych i empirycznych, przyrodniczych i humanistycznych.

Nowa fenomenologiczna filozofia ma być zatem, zgodnie z zamysłami Husserla, nauką bezzałożeniowa, ścisłą tzn. rygorystyczną metodologicznie i dzięki temu maksymalnie adekwatną do opisywanego stanu rzeczy oraz apodyktyczna, bo opierająca się na ejdetycznych związkach pomiędzy istotami badanych przedmiotów - związkach, którymi rządzi konieczność 
dorównująca konieczności matematycznej, bo są to związki aprioryczne, choć wykrywane dopiero w wyniku wglądu uzyskanego dzięki redukcji ejdetycznej. Zdaniem Święcickiej, apodyktyczność fenomenologii ma jeszcze jeden ważny aspekt - aspekt etyczny. Absolutnie pewna wiedza przechodzi w „apodyktyczną wolność” w momencie, w którym rozum w swoim dążeniu do pewności rozpoznaje, że w ten sposób realizuje swoją naturę (Święcicka 1993: 109-110). Proces ten, zdaniem Husserla, jest nieskończony i musi być przekazywany i podejmowany przez kolejne pokolenia. Jest nieustannie podejmowanym trudem samowiedzy. A wejście na drogę samowiedzy rozumu jest koniecznym warunkiem odnowy duchowej ludzkości.

Owa wolność w dążeniu do racjonalności przejawia się w fenomenologii również w jej egalitaryzmie. Po pierwsze, do poznania fenomenologicznego nie jest potrzebna wiedza nauczana na uniwersytetach. Zabieg redukcji ma ją przecież „wziąć w nawias”. Fenomenolog ma oczyścić umysł z tej i każdej innej wiedzy. Po drugie, każdy może uprawiać fenomenologię, o ile będzie konsekwentnie postępował zgodnie z jej metodologicznymi zaleceniami. Wreszcie, po trzecie, ostateczną instancją orzekającą o zasadności wglądów fenomenologicznych jest samo doświadczenie. Husserl zdaje się mówić do swoich czytelników: nie musicie wierzyć mi na słowo, nie powinniście mi wierzyć, sami zmieńcie nastawienie na fenomenologiczne, stosując redukcję, i sprawdźcie, czy znajdziecie w swoim doświadczeniu struktury racjonalności, które opisuję.

Podsumowując ów wątek poszukiwania nowego początku dla odnowionej poprzez zaproponowaną metodę filozofii, można skonstatować, że w projekcie fenomenologii skrywa się odnowa samej racjonalności. Jej nowy model ma gwarantować apodyktyczne fundamenty wszelkiej wiedzy, teoretycznej i praktycznej. W pierwszym rzędzie odnowiona racjonalność ma prowadzić do odnowy nauk. Ugruntowanie nauk empirycznych w fenomenologii ma sprawić, że nie będą one dłużej naiwne i ślepe na swoje podstawy, przez co przestaną się wikłać, z jednej strony, w niedorzeczne projekty naturalizacji świadomości, z drugiej zaś, w relatywizm światopoglądowy. Jednak dla Husserla sama odnowa nauk nie jest najważniejsza; wspomnieliśmy wszak o ważnym dla Husserla aspekcie etycznym. Najważniejsza jest odnowa duchowa człowieczeństwa i jego powrót na drogę dziejowego rozwoju racjonalności. Wyjście z kryzysu, w którym znalazła się cywilizacja europejska, zależy od rehabilitacji racjonalności bardziej wielowymiarowej niż racjonalność panująca w naukach szczegółowych, i to ona ma zaprowadzić ludzkość na drogę samowiedzy. Do odegrania pierwszorzędnej roli w tym dziele, podkreślmy to raz jeszcze, powołani są filo- 
zofowie - prawdziwi „funkcjonariusze ludzkości” (Husserl 2017: 35) - na których ciąży zadanie odkrywania ,uniwersalnego rozumu «wrodzonego» ludzkości jako takiej” (2017: 33).

\section{/// Porażka czy sukces?}

Przedstawiona powyżej skrótowa rekonstrukcja Husserlowskiego projektu duchowej odnowy „europejskiej ludzkości” pozwala skonstatować, że projekt ów cechuje swoisty fundamentalizm. Fundamentalizm zaś to taka postawa, która angażuje całe życie duchowe jej adherenta, jego uświadamiane motywy postępowania i wartości, ale też te pozostające w ukryciu, często irracjonalne. Sytuacja taka zdaje się iść w parze z nasza, wyrażona już na wstępie hipoteza, że wybór nowej drogi życiowej przez młodego Husserla miał w dużej mierze charakter przeżycia metafizycznego, religijnego. Zauważył to już zresztą Leszek Kołakowski, mówiąc, że Husserlowskie frenetyczne poszukiwanie pewności miało „tło religijne raczej niż intelektualne" (Kołakowski 1987: 38). Jakimś symptomem takiego duchowego nastawienia motywującego projekt nowej filozofii fenomenologicznej jest też przecież wypływająca z cytowanej wyżej „zasady wszystkich zasad” koncepcja poznania bezpośredniego, osiagającego w intuicyjnym „wglądzie” bezdyskusyjną styczność z samą istota badanego przedmiotu - styczność uzyskiwaną nie tylko dzięki naoczności zmysłowej, ale też dzięki naoczności podniesionej do rangi „kategorialnej”, czyli na poziom „oglądania” treści abstrakcyjnych pojęć (Husserl 2000b: 4-5, 13-14, 169-172; Husserl 1990: 66-77; Husserl 1967: 20-25). A to jest wszak przywilej przypisywany poznawaniu mistycznemu - i Husserl sam powiada: „faktycznie, nawiązujemy do sposobu wyrażania się mistyków, gdy ci opisują ogląd intelektualny nie będący wiedzą rozumową" (Husserl 1990: 76). Fundamentalizm Husserla ma jednak tę specyfikę, że pokłada największą ufność w nauce, bo jak czytaliśmy, „tylko nauka może przezwyciężyć nędzę, która pochodzi z nauki”. I tu wyłania się trawiący całe przedsięwzięcie Husserla kłopot. Z jednej strony bowiem fenomenologia Husserla stara się dotrzeć przy pomocy proponowanych narzędzi metodologicznych do ostatecznej „prapodstawy” wszelkich nauk, do ostatecznego czy najbardziej pierwotnego źródła wiedzy o tym, co jawi się w doświadczeniu - i to źródło ma być uchwycone $z$ apodyktyczną pewnością. $Z$ drugiej strony, właściwe postawie naukowej, ale też odziedziczone po tradycji transcendentalizmu nastawienie krytyczne, nakazujące zgodnie $\mathrm{z}$ zasadą bezzałożeniowości niestrudzenie i właściwie bez końca sprawdzać prawomocność uchwytywanych w analizach 
związków pomiędzy nieskończoną wielością zjawisk, skutkuje tendencją do ciagłego pogłębiania adekwatności uzyskanych opisów. Tendencja ta ma niewątpliwie charakter antyfundamentalistyczny. Otóż napięcie pomiędzy dążeniem do apodyktyczności a dążeniem do adekwatności, pomiędzy fundamentalizmem a antyfundamentalizmem przenika całe dzieło Husserla i jest zapewne jednym z powodów - oprócz zewnętrznych okoliczności historycznych i cech charakterologicznych osobowości filozofa swoistości fenomenologii Husserlowskiej. W zgodnej opinii niemal wszystkich komentatorów fenomenologię tę przenikają heteronomiczne, czasem nawet sprzeczne dążenia, co sprawia, że nie ma w niej żadnej ortodoksji. Można też doszukiwać się w tym wytłumaczenia faktu, że Husserl, jak wiadomo, prawie żadnego ze swych większych tekstów nie doprowadził do ostatecznego etapu publikacji i że był właściwie filozofem „wiecznie początkującym”. Poszukiwane przezeń ostateczne źródło pewności naukowej stale się przed jego badawczą dociekliwością cofało. Znalazło to wyraz w kolejnych ewolucyjnych etapach jego programu fenomenologicznego, który rozwijał się od „psychologii opisowej” Badań logicznych, poprzez „zwrot transcendentalny” dokonany w 1907 roku w Idei fenomenologii i rozwinięty w Ideach I, dalej poprzez zaakcentowanie roli „pasywnych syntez” ograniczających konstytutywną rolę świadomości i otwierających drogę do zawartych szczególnie w Ideach II analiz „ciała żywego” (niezbędnego dla nawiązania relacji intersubiektywnej), aż po, pozwólmy sobie go tak nazwać, „zwrot ontologiczno-kulturowy”, kulminujacy w priorytecie przyznanym sferze Lebenswelt, jaki występuje w ostatniej opublikowanej za życia pracy Husserla, w Kryzysie. Jak to dzisiaj widać z przeglądu niezliczonych komentarzy, w jakie obrosło całe dzieło Husserla, teoretycznych problemów szczegółowych, o jakie potykał się w swoich badaniach filozof, ale które były właśnie napędem wspomnianej ewolucji, było bez liku.

Dla przykładu przytoczmy kłopot, z jakim borykał się Husserl w kwestii centralnej dla jego projektu, mianowicie w kwestii samego pojęcia fenomenu - który to kłopot syntetycznie przedstawił Didier Franck (Franck 2001: 105-142). W klasycznym ujęciu fenomenologii transcendentalnej świat jest nieskończonym zbiorem fenomenów (czyli po przeprowadzonej redukcji przedmiotów „irrealnych”) jako wytworów przeżyć intencjonalnych. Przeżycia mają jednak złożoną strukturę - składają się z treści „wrażeniowych” i „popędowych” oraz z intencjonalnego momentu ujęcia przedmiotu przeżycia, nadającego mu sens tego właśnie, a nie innego przedmiotu. Do opisu tej pierwszej warstwy Husserl używa słowa bylé (materia czy raczej „materiał”), określając ja jako „daty hyletyczne”, 
materiały zmysłowe; tę drugą opisuje przy pomocy słowa morphé (forma ujęcia, będąca istotnym elementem noezy). Otóż kiedy widzę np. drzewo w ogrodzie, chociaż widzę je poprzez kolejne „wyglądy”, profile, to nie widzę moich treści wrażeniowych („dat hyletycznych”), tylko drzewo „we własnej osobie”. Sens fenomenu „drzewo” - mimo tego, że ukonstytuowany w przeżyciu składającym się z bylé zmysłowej i z morphé intencjonalnej - nie należy więc do warstwy hyletycznej przeżycia (pozbawionej zatem sensu), lecz do formalnego momentu intencjonalnego świadomości. Fenomenalność, a więc sens przedmiotowości należącej do świata i gwarantującej obiektywność budowanej wiedzy o nim, konstytuowana jest przez transcendentalną świadomość. Zarzut „idealizmu Berkeleyowskiego” który Husserl expressis verbis odrzuca (Husserl 1967: 182) - skierowany pod adresem idealizmu transcendentalnego, dla czytelników nieakceptujących postawy transcendentalnej, odnoszącej się nie do istnienia jakichś bytów, lecz do konstytucji sensu, wydawać się może uprawniony. Tymczasem jednak, kiedy Husserl chce adekwatnie opisać doświadczenie własnego Ja, to okazuje się, że poza doświadczeniem ,żywej teraźniejszości czystego Ja” - czyli samo-doświadczaniem czystej świadomości - rozpościera się to, co właściwie nie-doświadczane, choć z koniecznością współdomniemywane, czyli „ciemna zupełnie przeszłość czystego Ja” (Husserl 1982: 31-32), i tym samym staje przed nim zadanie fenomenologicznej analizy czasowości. Analiza ta nie obejmuje wszelako jedynie sfery samej świadomości intencjonalnej, lecz ma walor uniwersalny, bo przecież wszystkie ukonstytuowane fenomeny podlegaja przemianom czasowym.

W wyniku tej analizy (1989: 44-45, 94-102, 110-111, 113-116) Husserl odkrywa dwa różne fenomeny czasu: ten, który konstytuuje kolejne „przedmiotowe” momenty w czasie, czyli w subiektywnie przeżywanym strumieniu kolejnych „teraz” w otoczce ciagłych retencji i protencji, oraz ten, na który nie składają się żadne indywidualne obiekty, a który jest samym tym strumieniem, ,przepływem” wytryskujaccym nieustannie w płynącym punkcie „teraz”, będącym „praźródłem”. I oczywiście to ten drugi fenomen czasu, nazywany przez Husserla czasem absolutnym, jest ciągłym procesem ,wypływania coraz to nowego prabytu” - a jego płynącym punktem startowym jest praimpresja, „prawrażenie”. Tak więc jeśli chodzi o czas najbardziej pierwotny, absolutny, to nie morphé przeżycia poprzedzająca zmysłowa bylé, lecz materialna treść wrażeniowa przesuwającego się punktu czasowego, zwana praimpresją, czyli właśnie bylé czasowa jest źródłem intencjonalności nadającej sens przedmiotowy, a ostatecznie także źródłem wszelkiej świadomości i wszelkiego prezentującego się poprzez 
fenomeny bytu. Tyle tylko, że owo źródło dostępne jest zawsze poprzez retencję w modi „byłości” i źródłowa świadomość jest świadomością tego, co źródłowo niedostępne i nieosiaggalne. Husserl z pewną dozą rezygnacji powiada: „dla tego wszystkiego brak nam słów”. Problematyka konstytucji znalazła się w błędnym kole - z jednej strony sens fenomenalności, przedmiotowości transcendentalnej wywodzi się od intencjonalnej formy świadomości, z drugiej strony, intencjonalną formę wywodzi się z materii, sens ze zmysłowości, formy znaczeniowe ze sposobów odczuwania. Czy nie oznacza to, że fenomenologia nie znalazła właściwej nazwy dla swojego fenomenologicznego absolutu i dla samej fenomenalności i czy nie obliguje to jej do wykroczenia poza swoje, ugruntowane w skodyfikowanej metodzie granice? Czy w związku z tego rodzaju trudnościami można mówić, że obietnica odnowy filozofii i pokonania kryzysu duchowego została dotrzymana?

Mimo tego, że w przedsięwzięciu Husserla zwanym fenomenologia można znaleźć jeszcze, jak mówiliśmy, sporo innych kłopotów teoretycznych, które niestrudzenie pokonywał, nie sądzimy, by można je było w jakimkolwiek wymiarze ocenić jako porażkę. Przeciwnie, skłaniamy się do opinii, że zaproponowana przez Husserla „filozofia radykalnego początku” okazała się ostatecznie sukcesem, choć kolejne i to poważniejsze „kryzysy” zdają się być nieszczęsnym przeznaczeniem naszego świata. Za uznaniem jej za sukces przemawiaja przede wszystkim dwie okoliczności. Po pierwsze, Husserlowska propozycja odnowy filozofii i pokonania kryzysu duchowego Europy była tak nowatorska, że przyczyniła się do przełamania zastygłych scjentystyczno-pozytywistycznych i relatywistycznych, historycystycznych schematów myślowych panujących w filozofii na przełomie XIX i XX wieku - i przywróciła filozofii jej prawdziwie metafizyczne powołanie (pytając o ostateczne źródła sensu), jednocześnie wykazując dzięki nowym metodologicznym narzędziom teoretyczna płodność w analizach różnych dziedzin wiedzy i kultury (naukoznawstwa, moralności, religii, sztuki, polityki). Dzieło Husserla, mimo przenikających je heteronomicznych napięć, było istotnym ogniwem pokonywania zdiagnozowanego kryzysu kultury właśnie dlatego, że jak dowodzi Kołakowski, to „raczej konflikt wartości niż ich harmonia utrzymuje naszą kulturę przy życiu” (Kołakowski 1987: 39). Efekty tej odnowy można śledzić w pracach już nie tylko Husserla, ale też innych, mniej lub bardziej znanych fenomenologów. Po drugie, sukcesem fenomenologii jest niewatpliwie to, że ukształtowała się w historycznie ważny ruch filozoficzny - bo może nie w zwartą szkołę czy system - o czasami zmiennej, ale nieustająco odradzającej się dynamice 
rozwojowej. I może właśnie te momenty owego „ruchu”, które balansowały na granicach pierwotnie przyjętych zasad programowych i które prowokowały do wysuwania coraz poważniejszych teoretycznych zastrzeżeń co do ich fenomenologicznej tożsamości, okazywały się najbardziej żywotne. Stawiały bowiem pytania rozjątrzające dyskurs filozoficzny, od których żadna poważna filozofia nie może się uchylić. Przykładów tego zjawiska - na których opisanie nie ma tu z oczywistych względów miejsca - dostarcza szczególnie ten etap ruchu fenomenologicznego, który miał miejsce w końcówce XX stulecia.

$\mathrm{Na}$ koniec powróćmy do pytania o charakter przemiany, jaka miała miejsce w biografii intelektualnej Husserla i która podyktowała mu program pokonania kryzysu trawiącego Europe - czy miała ona cechy wewnętrznego przełomu duchowego, angażującego całą osobowość filozofa, łącznie z najbardziej zinterioryzowanymi skłonnościami światopoglądowymi, czy może był to po prostu nowatorski projekt teoretyczny, wyrosły z przemyślenia niedostatków panującej tradycji filozoficznej. Mając świadomość, że oba te motywy w różnych rewolucjach filozoficznych często występuja łącznie, choć w różnych natężeniach, opowiadamy się w przypadku Husserla za pierwszym rozstrzygnięciem. Co więcej, można domniemywać, że Husserl umierał z poczuciem duchowego spełnienia, swoistego zwieńczenia podjętej misji. Niech o tym świadczą słowa, wypowiedziane na łożu śmierci do żony, kiedy przebudzony z głębokiego snu, z wyraźnymi oznakami radości na twarzy, wyznal jej: Ich habe etwas ganz Wunderbares gesehen. Nein, ich kann es Dir nich sagen. Nein! - „Zobaczyłem coś całkiem cudownego. Nie, nie mogę ci tego powiedzieć. Nie!” (Franck 2017: 215).

Bibliografia:

/// Franck D. 2001. Dramatique des phénomènes, PUF.

/// Franck D. 2017. Dwa ciała. Wokót fenomenologii Husserla, tłum. J. Migasiński, A. Dwulit, Wydawnictwo Naukowe Scholar (cytat za: Schumann K. 1977. Husserl-Chronik. Denk-und Lebensweg Edmund Husserls, „Husserliana Dokumente", nr 1, Martinus Nijhoff, s. 489).

/// Gniazdowski A. 2007. Polityka i geometria. Fenomenologia Edmunda Husserla a problem demokracji, IFiS PAN.

/// Husserl E. 1967. Idee czystej fenomenologii i fenomenologicznej filozofii, księga I, (Idee I), tłum. D. Gierulanka, PWN. 
/// Husserl E. 1974. Idee czystej fenomenologii i fenomenologicznej filozofii, księga II, (Idee II), tłum. D. Gierulanka, PWN.

/// Husserl E. 1982. Medytacje kartezjańskie, tłum. A. Wajs, PWN.

/// Husserl E. 1989. Wyktady z fenomenologii wewnętrænej swiadomości czasu, tłum. J. Sidorek, PWN.

/// Husserl E. 1990. Idea fenomenologii. Pieć wylkładón, tłum. J. Sidorek, PWN.

/// Husserl E. 1992. Filozofia jako ścisła nanka, tłum. W. Galewicz, Aletheia.

/// Husserl E. 1993. Kryzys europejskiego człowieczeństwa a filozofia, tłum. J. Sidorek, Aletheia.

/// Husserl E. 2000a. Badania logicそne, t. II, cz. I, tłum. J. Sidorek, PWN.

/// Husserl E. 2000b. Badania logic₹ne, t. II, cz. II, tłum. J. Sidorek, PWN.

/// Husserl E. 2009. List Edmunda Husserla do Arnolda Metagera, tłum. A. Gniazdowski, „Przegląd Filozoficzny. Nowa Seria”, R. 18, nr 4(72), s. $537-544$.

/// Husserl E. 2011. Logika formalna i logika transcendentalna. Próba krytyki rozumu logic₹nego, tłum. G. Sowinski, IFiS PAN.

/// Husserl E. 2017. Kryzys nauk europejskich i fenomenologia transcendentalna, tłum. S. Walczewska, Vis-à-Vis Etiuda.

/// Kołakowski L. 1987. Husserl i poszukiwanie pewności, In Plus.

/// Krokos J. 1998. Metody fenomenologiczne i ich aktualnosíc: zarys problemu, „Studia Philosophiae Christianae”, nr 34/2, s. 103-111.

/// Lee Chun Lo 2009. Teleologia świata i idea Boga. Znacženie Boga w fenomenologii Husserla, z niemieckiego tłum. J. Duraj, „Przegląd Filozoficzny. Nowa Seria", R. 18, nr 4(72), s. 337-351.

/// Laciak P. 1015. Fenomenologia transcendentalna i metafiryka, „Archiwum Historii Filozofii i Myśli Społecznej”, t. 60, s. 256-277.

/// Merleau-Ponty M. 2001. Fenomenologia percepcji, tłum. M. Kowalska, J. Migasiński, Aletheia.

/// Metzger A. 1979. Pbänomenologie der Revolution, Syndikat.

/// Miettinen T. 2013. The Idea of Europe in Husserl's Phenomenology: A Study in Generativity and Historicity, University of Helsinki. 
/// Mohanty J., Frege G., Husserl E. 1974. Frege-Husserl Correspondence, „, The Southwestern Journal of Philosophy", nr 5(3), s. 83-95.

/// Płotka W. 2019. Fenomenologia jako filozofia mniejsza. Rozważania wokót sporów o metode Husserla, Wydawnictwo Liberi Libri.

/// Spiegelberg H. 1972. The Phenomenological Movement, Springer.

/// Święcicka K. 1993. Husserl, „Wiedza Powszechna”.

/// Zahavi D. 2012. Fenomenologia Husserla, Wydawnictwo WAM.

\section{/// Abstrakt}

W artykule omawiamy na podstawie prac Edmunda Husserla oraz korespondencji z jego uczniem Arnoldem Metzgerem wybrane idee fenomenologii, pokazując, jak bardzo radykalny i maksymalistyczny był to projekt, który w skrócie można scharakteryzować jako próbę rozpoczęcia filozofii od nowa. Wychodząc od skrajnie pesymistycznej oceny filozofii i nauki, Husserl opisuje kryzys racjonalności, który dotknął Europę. Rozwiązaniem ma być stworzenie nowej, ściśle naukowej filozofii, czyli fenomenologii. Wedle zamysłów Husserla, miała ona stanowić całkiem nową fundamentalną dyscyplinę naukową dającą podstawę innym naukom, w tym m.in. psychologii. Zadanie, jakie sobie Husserl postawił, wymagało radykalnych środków, dlatego dużą część swoich rozważań poświęcił na opracowanie nowej metody filozoficznej, której celem było m.in. zawieszenie całej uprzednio nabytej wiedzy. Maksymalistyczny projekt Husserla zmagał się z wewnętrznymi ograniczeniami i sprzecznościami, doprowadził jednak do przełomu teoretycznego w filozofii XIX i XX wieku. Cel tak pomyślanej nowej filozofii nie był wyłącznie naukowy, lecz również cywilizacyjny. Fenomenologia miała doprowadzić do odnowy duchowej ludzkości poprzez transformację nauki i odkrycie nieskończonej idei racjonalności leżącej u podstaw kultury europejskiej.

Słowa kluczowe:

fenomenologia, Husserl, kryzys, redukcja fenomenologiczna 


\section{/// Abstract}

\section{Husserl and the Philosophy of Radical Beginnings}

In this article the authors introduce the radical project of phenomenological philosophy and argue that the idea behind the project was to give philosophy a new beginning. The authors refer to selected works of Edmund Husserl and to his correspondence with Arnold Metzger. They discuss Husserl's critique of philosophy and science, and his motivations for creating a new scientific philosophy, which applies a radical method of reduction. According to Husserl, the new phenomenological philosophy will ultimately lead to overcoming the crisis of rationality and to the spiritual renewal of humanity.

Keywords:

phenomenology, Husserl, crisis, phenomenological reduction

/// Jacek Migasiński - emerytowany profesor Uniwersytetu Warszawskiego, autor wielu artykułów i przekładów dotyczących filozofii francuskiej oraz m.in. książek: Maurice Merleau-Ponty, Warszawa 1995, W strone metafizyki. Nowe tendencje metafiæyczne w filozofii francuskiej XX wieku, Wrocław 1997 (II wyd. Toruń 2014), Filozofia nowożytna, Warszawa 2011, W strone fenomenologii niezjawiskowej, Warszawa 2019 - a także redaktor naukowy m.in. antologii Fenomenologia francuska (wraz z Iwoną Lorenc), Warszawa 2006 i Gtówne problemy wspótczesnej fenomenologii (wraz z Markiem Pokropskim), Warszawa 2017.

ORCID: https://orcid.org/0000-0003-4267-0785

E-mail: j.migasinski@uw.edu.pl

/// Marek Pokropski - adiunkt w Instytucie Filozofii Uniwersytetu Warszawskiego. Zajmuje się fenomenologią, filozofią umysłu i filozofią nauk kognitywnych. Autor artykułów i monografii pt. Cielesna geneza cz̧asu i prz̨estrzeni (Warszawa 2013). Redaktor naukowy (razem z Jackiem Migasińskim) antologii Gtówne problemy wspótczesnej fenomenologii (Warszawa 2017).

ORCID: https://orcid.org/0000-0002-7423-6951

E-mail: mpokropski@uw.edu.pl 